\title{
Survey on the effects of pre-treatment process with acid on the capacity of gelatin extraction from pork skin
}

\author{
Khảo sát ảnh hưởng của quá trình tiền xủ lý bằng axit đến khả năng trích ly \\ gelatin tù bì lợn \\ Research article
}

Nguyen Truong Giang*; Nguyen Thi Nga; Vu Thi Tuyet; Bui Thi Ngoan

School of Biotechnology and Food technology, Hanoi University of Science and Technology, 01 Dai Co Viet Str., Hai Ba Trung, Hanoi, Vietnam

\begin{abstract}
Gelatin is increasingly becoming an important raw material in many different fields. The pretreatment stage of the production of gelatin from pork skin plays an important role, it has big effect on the quality of obtained products. A survey on 5 types of acid $\mathrm{HCl}, \mathrm{H}_{2} \mathrm{SO}_{4}, \mathrm{H}_{3} \mathrm{PO}_{4}, \mathrm{CH}_{3} \mathrm{COOH}$, Citric was conducted. It showed that the influence of these types of acid on the pretreatment process was different. Acetic acid made the best result with the protein after extraction reaching $54.88 \mathrm{mg} / \mathrm{ml}$, the product bloom reached 223. The most appropriate proportion of acetic acid was $3 \%$. A survey on the effect of soaking time on the capacity of extraction was conducted. The result showed that the 16-hour extraction brought the best result reaching $56.16 \mathrm{mg} / \mathrm{ml}$, the product bloom reached 245 . The most suitable proportion of soaking pork skin:acid was 1:2. The most appropriate temperature of acid immersion was $15^{\circ} \mathrm{C}$, at which the protein after extraction reached $68.39 \mathrm{mg} / \mathrm{ml}$, the product bloom reached 299, the viscosity reached $23 \mathrm{mPas}$.
\end{abstract}

Gelatin ngày càng trở thành nguồn nguyên liệu quan trọng trong nhiều lĩnh vục khác nhau. Giai đoạn tiền xử lý của việc sản xuất gelatin tù bì lợn đóng vai trò quan trọng và có ảnh hưởng lớn tới chất lượng sản phẩm thu được. Khảo sát 5 loại axit: $\mathrm{HCl}, \mathrm{H}_{2} \mathrm{SO}_{4}, \mathrm{H}_{3} \mathrm{PO}_{4}, \mathrm{CH}_{3} \mathrm{COOH}$, Citric, thấy rằng ảnh hưởng của các loại axit này trong quá trình tiền xử lý là khác nhau. Axit axetic cho kết quả tốt nhất với hàm luợng protein sau trich ly đạt $54,88 \mathrm{mg} / \mathrm{ml}$, độ bloom sản phẩm đạt 223. Nồng độ thich hợp nhất của axit axetic là 3\%. Khảo sát ảnh hưởng của thời gian ngâm đến khả năng trích ly thấy rằng 16 giờ cho kết quả tốt nhất đạt $56,16 \mathrm{mg} / \mathrm{ml}$, độ bloom sản phẩm đạt 245. Tỷ lệ ngâm bì lọn: axit thich hợp nhất là $1: 2$. Nhiệt độ ngâm axit thích hợp nhất là $15^{\circ} C$, tại đó hàm lương protein sau trich ly đạt $68,39 \mathrm{mg} / \mathrm{ml}$, độ bloom sản phẩm đạt 299, độ nhớt đạt $23 \mathrm{mPs}$.

Keywords: gelatin, pigskin, pretreatment process

\section{Introduction}

Gelatin is increasingly becoming an important raw material in many different fields, especially in food technology The sources of raw materials for producing gelatin are relatively rich such as pork skin, cow skin, fish skin, animal bones... Taking advantage of available and cheap raw materials not only brings economic benefit but also contributes to solve environmental issues. Pork skin is the available and cheap raw material in Vietnam. Gelatin production from pork skin is not proportional to the material potential. In the production process of gelatin from pork skin, the pretreatment stage plays an important role, it has big effect on the quality of obtained products. The research of the pretreatment process contributes significantly to the production of gelatin from this available material.

\section{Materials and research method}

\subsection{Materials and chemicals}

Pork skin was bought at the market near Hanoi University of Science and Technology, stored at $-20^{\circ} \mathrm{C}$ not exceed 5 days until being analysed. Acids including $\mathrm{HCl}, \mathrm{H}_{2} \mathrm{SO}_{4}$, $\mathrm{H}_{3} \mathrm{PO}_{4}$, citric, $\mathrm{CH}_{3} \mathrm{COOH}, \mathrm{KNaC}_{4} \mathrm{H}_{4} \mathrm{O}_{6}, \mathrm{CuSO}_{4}, \mathrm{NaOH}$, 
$\mathrm{CH}_{3} \mathrm{OH}$ were from Daejung company, Korea. The chemicals for electrophoresis (acrylamide, SDS, ammonium persulfate, bromophenol blue, tris- $\mathrm{HCl}$, coomasie brilliant blue, glycerol, $\beta$-mercapthoethanol, temed) are from Merck company, Germany.

\subsection{Research methods}

Method of experiment arrangement: The experiments were conducted with 5 different types of acid including $\mathrm{HCl}$, $\mathrm{H}_{2} \mathrm{SO}_{4}, \mathrm{H}_{3} \mathrm{PO}_{4}$, citric and $\mathrm{CH}_{3} \mathrm{COOH}$. Firstly, a survey on the influence of each type of acid was conducted at concentration as $1 \%$; the proportion of material-acid was $1-1$; soaking the mixture in 12 hours at $30^{\circ} \mathrm{C}$. After selecting the appropriate type of acid, it is the time to select the appropriate concentration of acid (from 0.5 to $6.0 \%$ ), appropriate soaking time (from 8 to 16 hours), material-acid proportion (survey with proportion 1-1, 1-2, 1-3, 1-4) and appropriate soaking temperature (survey with temperature $15-35^{\circ} \mathrm{C}$ ). Each experiment was repeated three times.

Method of processing experimental figure: The experimental figure was averaged and processed with Microsoft Office Excel 2007 with the error under 5\%.

Method of pretreatment, gelatin extraction and receiving: Pork skin was chopped with size $2 \times 2 \mathrm{~cm}$, soaked in acid with the appropriate proportion and time, then washed with water 3 times. Pork skin and water were put together with the proportion of pork skin:water as 1: 3, extracted in the tank of thermostat at $60^{\circ} \mathrm{C}$ for 3 hours. The liquid after extraction was centrifuged at 6000 revolution per minute to remove grease, filtered through ion filter to remove mineral, then dried at $40^{\circ} \mathrm{C}$ for 6 hours until the humidity reached $10 \%[2,6,7]$.

Method of determining the ash content: The ash content was determined by combustion at $600^{\circ} \mathrm{C}$ for 4 hours [4].

Method of determining the humidity content: The humidity content was determined by drying until reaching constant weight at $105^{\circ} \mathrm{C}$ [4] with Memmert UN55 oven, Germany.

Method of determining the gel strength: The gel strength was determined by the method of BSI, 1975 [1] on TA.TX plus Stable Micro Systems.

Electrophoresis method determining the protein component: Denatured electrophoresis SDS on polyacrylamide gel through the method of Laemmli (1970) [3,8,9] with Gangnamstyle maker was used to determine the size of protein in the liquid after extraction. Gelatin after extraction was diluted 50 times with distilled water used for experiment.

Method of calculating the reclaimation performance: The reclaimation performance of product was calculated based on the rate of the amount of obtained gelatin and the amount of gelatin in raw material (calculated based on humidity and protein content in raw material).

\section{Results and discussion}

\subsection{Effect of the acids in the pre-treatment stage of raw material on the ability of gelatin extraction}

Effect of the acids in the pre-treatment stage on the quality of gelatin is shown in Figure 1 and 2 .

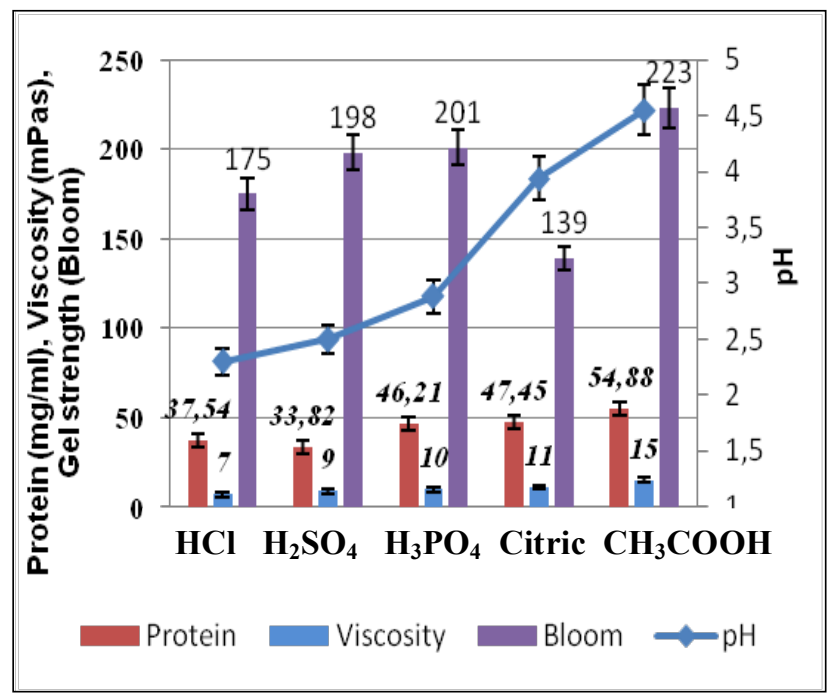

Figure 1. Effect of the acids in the pretreatment stage on the ability of gelatin extraction

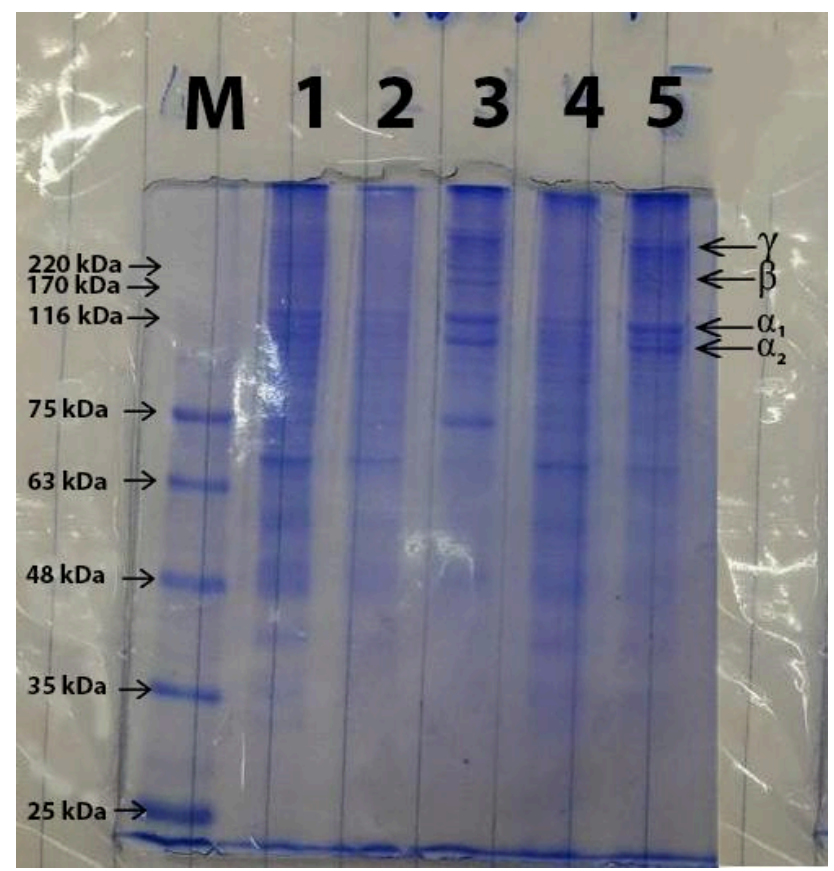

Figure 2. Electrophoresis result SDS-PAGE gelatin after extraction (using different acids for the pretreatment stage: 1- $\mathrm{H}_{3} \mathrm{PO}_{4}$, 2-Citric, 3-HCl, 4- $\mathrm{H}_{2} \mathrm{SO}_{4}$, 5- $\mathrm{CH}_{3} \mathrm{COOH,} \mathrm{M-marker)}$

From the result in Figure 1, it can be seen that acetic acid brought the best results: The gel strength reached around 223 , the protein content on the liquid after extraction reached $54.88 \mathrm{mg} / \mathrm{ml}$, the viscosity reached $15 \mathrm{mPas}$. Besides, the $\mathrm{pH}$ of extraction liquid from the pre-treatment stage with acetic acid also brought the best result about 4.5 . 
It is the fact that the $\mathrm{pH}$ greatly affects the viscosity and the gel strength of gelatin [6], the obtained product has good quality if the $\mathrm{pH}$ is more than 4.0. Electrophoresis results (Figure 2) also showed that the pre-treatment stage with acetic acid and $\mathrm{H}_{3} \mathrm{PO}_{4}$ brought the best result, the $\alpha, \beta$ and $\gamma$ chain clearly appeared. Meanwhile, citric acid and $\mathrm{H}_{2} \mathrm{SO}_{4}$ brought the worse result. Therefore, acetic acid was chosen for the next experiments.

\subsection{Effect of the concentration of acetic acid in the pre-treatment satge on the ability of gela- tin extraction}

Acetic acid was diluted with the concentration from 0.5 to $6 \%$. The result showed that the quality of obtained extraction liquid with the concentration of acetic acid $3 \%$ was the best: the bloom reached about 217 , the viscosity reached $21 \mathrm{mPas}$ (Figure 3). This can be explained that the acid with low concentration does not strongly impact on the collagen structure leading to low extraction efficiency. Conversely, with high concentration, the acid strongly breaks the structure of helix chain so that the extraction does not get the desired components. The quality of obtained gelatin is not high then. This is similar to the studies of Mehdi Nikoo et al. [5].

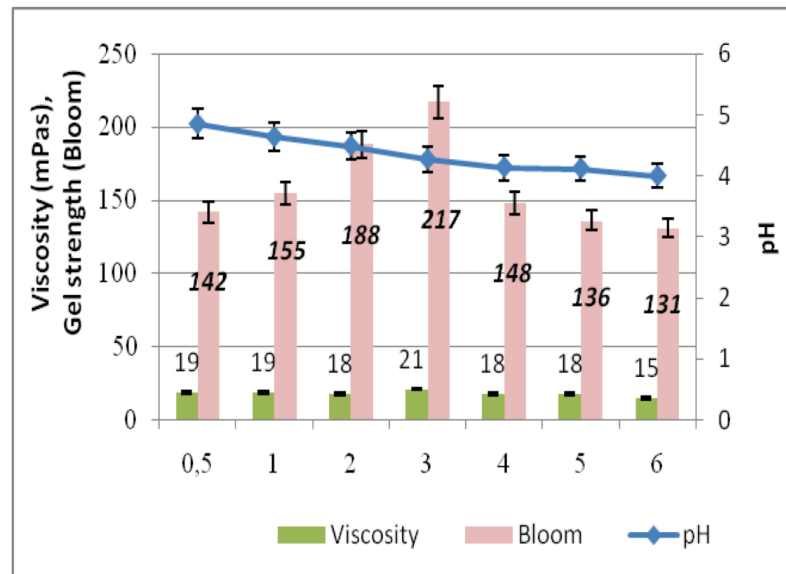

Figure 3. Effect of the concentration of acetic acid on the ability of gelatin extraction

\subsection{Effect of acid soaking time on the ability of gelatin extraction}

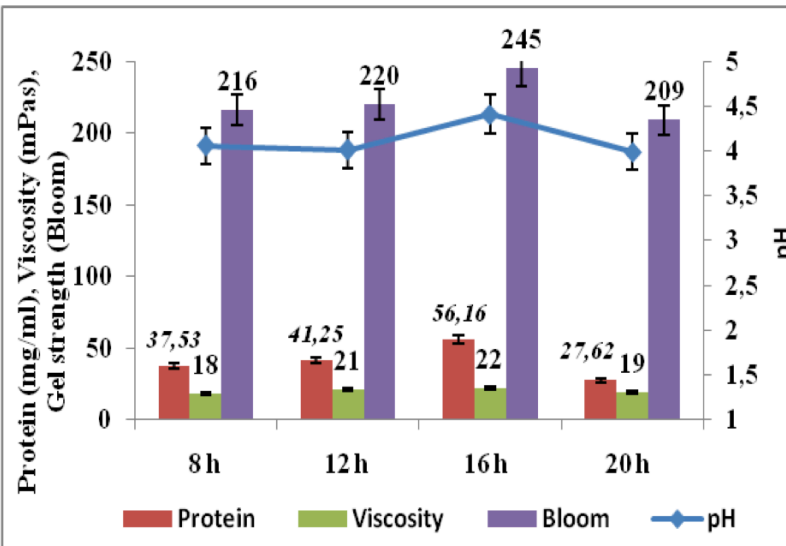

Figure 4. Effect of acetic acid soaking time on the ability of gelatin extraction
In the soaking process, the acid made collagen structure loose and easy to be extracted into gelatin during the extraction. Therefore, the time of soaking material in acid also strongly affected the quality of gelatin after extraction. According to the survey result, gelatin with the best quality was obtained after 16 hours of soaking, the gel strength of the product reached about 245, the viscosity reached 22 $\mathrm{mPas}$, the $\mathrm{pH}$ of the extraction liquid reached about 4.4 (Figure 4). This soaking time was applied to the next experiment.

\subsection{Effect of the proportion of raw material and acid in the pretreatment stage on the abil- ity of gelatin extraction}

The proportion of raw material and acetic acid 3\% (after 16 hours of soaking) also affected the result of gelatin extraction from raw material, which is shown in Figure 5. The most appropriate proportion of raw material : acid was 1 : 2 , the higher proportion of acid (1:3,1:4) did not make the extraction better (Figure 5).

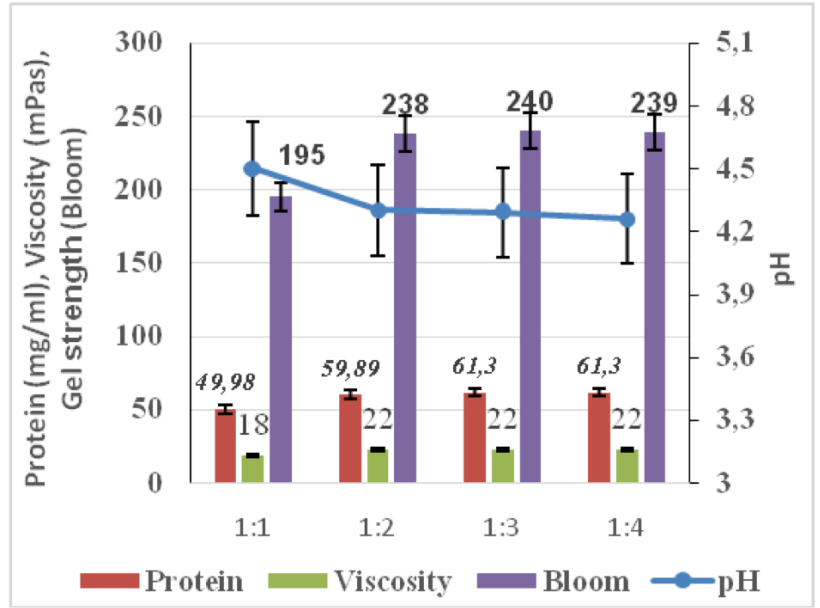

Figure 5. Effect of the proportion of raw material and acid on the ability of gelatin extraction

\subsection{Effect of the soaking temperature in the extraction process}

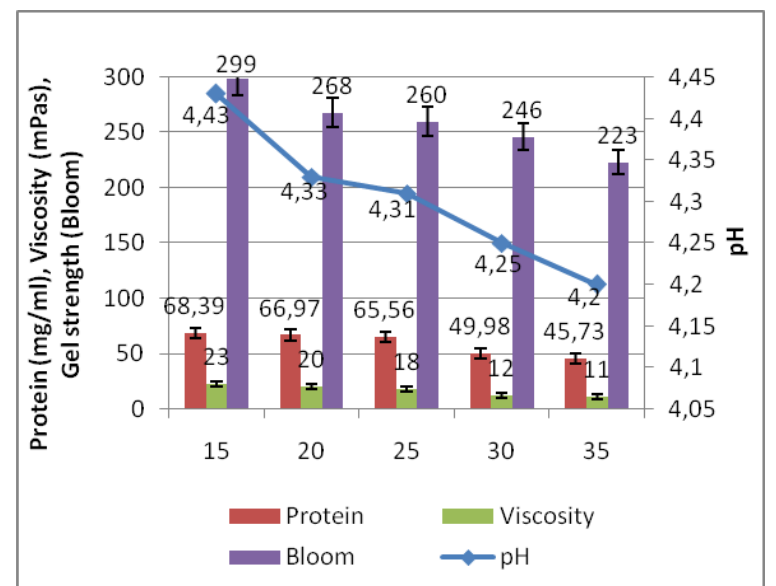

Figure 6. Effect of the temperature of soaking raw material in acid on the ability of gelatin extraction 
According to the previous research on gelatin extraction [7], the temperature of soaking raw material in acid also affects gelatin extraction because the temperature also affects the interaction between raw material and acid. The study result showed that the lower soaking temperature made the better quality of obtained gelatin; the higher concentration of gelatin in the extraction liquid, the higher $\mathrm{pH}$ of liquid after extraction (Figure 6).

After selecting the appropriate conditions of pretreatment with acid (concentration, soaking time, the proportion of raw material, the soaking temperature), the obtained gelatin had the protein content reaching $68.39 \mathrm{mg} / \mathrm{ml}$, the viscosity $23 \mathrm{mPas}$, the gel strength 299 , the humidity $9.8 \%$, the ash $0.3 \%$. The reclaimation performance of gelatin reached $85.24 \%$.

\section{Conclusion}

The process of pretreatment with acid greatly affects the extraction and the quality of obtained gelatin. The different types of acid have different effects on the pretreatment process. The most appropriate concentration of acetic acid for the pretreatment is $3 \%$. The most appropriate time of pretreatment stage is 16 hours, with the proportion of raw material: acid is 1: 2 . The most appropriate soaking temperature in the experiment is $15^{\circ} \mathrm{C}$. The obtained gelatin after selecting the appropriate conditions of pretreatment with acid has the protein content reaching $68.39 \mathrm{mg} / \mathrm{ml}$, the viscosity $23 \mathrm{mPas}$, the gel strength 299 , the humidity $9.8 \%$, the ash $0.3 \%$. These criterias of product meet the standards of food gelatin. The reclaimation performance of gelatin reaches $85.24 \%$.

\section{References}

[1] BSI, 1975. British Standard Institution, Methods for Sampling and Testing Gelatin (Physical and Chemical. Methods). British Standards Institution, BS No.757.

[2] Gelatin Manufacturers Institute of America (2012). Gelatin handbook.

[3] Laemmli, U. K. (1970). Cleavage of structural proteins during the assembly of the head of bacteriophage T4. Nature, 227(5259), 680-685.

[4] Le Thanh Mai, Nguyen Thi Hien, Pham Thu Thuy, Nguyen Thanh Hang, Le Thi Lan Chi (2004). The analytical method of fermentation industry. Science and Technology Publishing House (in Vietnamese).

[5] Mehdi Nikoo, Soottawat Benjakul, Mohanad Bashari, Masood Alekhorshied, Abdoulaye Idrissa, Na Yang, Xueming Xu (2014). Physicochemical properties of skin gelatin from farmed Amur sturgeon (Acipenser schrenckii) as influenced by acid pretreatment. Food Biosciense 5, 19-26.

[6] Mihai Sebastian (2014). Industrial gelatin manufacture - Theory and Practice.

[7] Pham Thi Quynh (2015). Advanced research performance gelatin extraction and purification processes for food processing from pork skin gelatin. Hanoi University of Science and Technology (in Vietnamese).

[8] Sittichoke Sinthusamran, Soottawat Benjakul, Hideki Kishimura (2014). Characteristic and gel properties of gelatin from skin of seabass (Lates calcarifer) as influenced by extraction conditions. Food Chemistry $152,276-284$.

[9] Sittichoke Sinthusamran, Soottawat Benjakul, Hideki Kishimura (2015). Molecular characteristics and properties of gelatin from slin of seabass with different sizes. International Journal of Biological Macromolecules $73,146-153$. 